\title{
Covid-19 Döneminde Akademisyen Annelerin İş-Yaşam Deneyimlerini Anlamak: Nitel Bir Araştırma
}

\author{
Understanding The Work-Life Experiences of \\ Academic Mothers During The Covid-19 Period: \\ A Qualitative Reserach
}

K. Övgü Çakmak Otluoğlu*

Benan Kurt Yllmaz**

Olca Sürgevil Dalkılıç***

\begin{abstract}
Özet
Covid-19 salgınıyla üniversiteler uzaktan eğitim sistemine geçmiş, akademisyenler eğitim faaliyetlerini evden yürütmek durumunda kalmışlardır. Söz konusu bağlamda, akademisyenlerin çalışma şekilleri önemli düzeyde etkilenmiş; akademik yükseltmelerde kritik başarı göstergesi olan yayın yapma faaliyetlerinin de evden gerçekleştirilmesi gerekmiştir. Bu durum, salgının önlenmesi için alınan tedbirlerle (örneğin: sosyal izolasyonun sağlanması için yardımcı ve bakıcı desteklerinin alınamaması) birleşince, ev içi yükleri de arttırmış, bu koşullar özellikle akademisyen annelerin kariyerlerini ve çalışma şekillerini etkilemiştir. Salgının devam etmesiyle
\end{abstract}

* Doç. Dr., İstanbul Üniversitesi İşletme Fakültesi, İşletme Bölümü, İnsan Kaynakları Yönetimi Anabilim Dalı, İstanbul, Türkiye. ovgu@istanbul.edu.tr, 0000-0002-8489-9345

** Öğr. Gör. Dr., Sinop Üniversitesi, Ayancık Meslek Yüksekokulu, Yönetim ve Organizasyon Bölümü, Sinop, Türkiye. bkurt@sinop.edu.tr, 0000-0002-1265-7136

*** Doç. Dr., Dokuz Eylül Üniversitesi, İktisadi ve İdari Bilimler Fakültesi, İşletme Bölümü, Yönetim ve Organizasyon Anabilim Dalı, İzmir, Türkiye, olca.surgevil@deu.edu.tr,0000-0002-7667-8104

Başvuru: 05.03.2021

Kabul: 26.03.2021

DOI: $10.21798 /$ kadem. 2021.50
This work is licensed under the Creative Commons Attribution 4.0 International License.

Cite this article as: Çakmak Otluoğlu, K.Ö., Kurt Yılmaz, B. ve Survegil Dalkılıç, O. (2021). Covid-19 Döneminde Akademisyen Annelerin Iş-Yaşam Deneyimlerini Anlamak: Nitel Bir Araştırma, Kadem Kadın Araştırmaları Dergisi, Vol. 7, No. 1: 13-52. 
üniversiteler uzaktan eğitimi sürdürmüş, bu dönemde akademisyen annelerin iş-yaşam dengeleri, akademik üretkenlikleri-verimlilikleri ve kariyerlerinin nasıl etkilendiği önemli bir araştırma sorusu olarak belirginleşmiştir. Bu araştırma sorusundan hareketle çalışmamızda, yirmi akademisyen anneyle derinlemesine görüşmeler gerçekleştirilerek salgın döneminde deneyimlenen işyaşam dengesizlikleri ve kariyer sorunları irdelenmiştir. Maxqda 2020 Plus programıla gerçekleştirilen analizler sonucunda, iş-aile çatışması ve akademik verimsizlik temaları belirgin bir şekilde ortaya çıkmıştır. Araştırmanın, salgının beraberinde getirdiği farklı sorumlulukları ve sorunları ortaya koyarak alınabilecek önlemlere ışık tutabileceği düşünülmektedir.

\begin{abstract}
With the Covid-19 outbreak, universities switched to the distance education system, and academics had to carry out their educational activities from home. This situation significantly affected the working style of academics; publishing activities, which are critical indicators of success in academic promotion, had to be carried out from home. Combined with the measures taken to prevent the epidemic (for example, lack of assistance and caregiver support to ensure social isolation), house responsibilities have also increased and these conditions have particularly affected the careers and working styles of academic mothers. With the continuation of the epidemic, universities also continued distance education, and it became clear as an important research question how the work-life balance, academic productivity-efficiency, and professional careers of academic mothers were affected during this period. Based on this research question, in our study, in-depth interviews with twenty academic mothers were conducted to examine work-life imbalances and career problems experienced during the epidemic period. As a result of the analysis carried out with the Maxqda 2020 Plus program, the themes of work-family conflict and academic inefficiency have emerged prominently. It is thought that the research can shed light on the measures that can be taken by revealing the different responsibilities and problems brought about by the epidemic.
\end{abstract}

\title{
Extended Abstract
}

Covid-19 epidemic does not only threaten public health, but also affects daily life both economically and socially. One of the most significant and traumatic effects of the Covid-19 epidemic is gender inequality. Due to remote work, which is used to ensure social 
distance and social isolation, it is seen that household and caring responsibilities are distributed disproportionately among even highly educated dual career couples. Even though these inequalities were also present before the epidemic, working mothers had at least support mechanisms such as schools, daycares, caregivers, and grandparents. Since such support mechanisms have been lost, it is argued that working mothers' careers are likely to suffer in the short and long term, including in academia. Because universities switched to distance education system, academics had to work from home as well. Combined with the measures taken to prevent the epidemic (for example, lack of assistance and caregiver support to ensure social isolation), household and caring responsibilities of academic mothers have also increased. These responsibilities have affected the careers and working styles of academic mothers. With the ongoing Covid-19 epidemic, universities continue distance education, and it becomes clear as an important research question how the work-life balance, academic productivity-efficiency, and professional careers of academic mothers are affected during this period. Hence, this study aims to investigate the problems faced by academic mothers, who represent a specific group of working mothers, in terms of work-life balance and career issues during the Covid-19 epidemic.

The general purpose of this research is to understand the work-life experiences of academic mothers who conduct distance education during the Covid-19 epidemic. There are three main reasons for focusing on academic mothers in this study. First, the decision to switch to distance education was taken at universities to prevent the spread of the epidemic. With this decision, activities such as lecturing, exams, jury membership, etc. moved to online platforms. Therefore, academic mothers are included in the group that experience remote work. Second, academy is a profession that includes research activities as well as educational activities. Moreover, the number of publications included among research activities constitutes a critical success factor for the promotion of academics. Inequalities in household chores caused by gender roles, especially full-time childcare, are predicted to negatively affect the publishing productivity of academic mothers. In this context, it is thought to be of importance to investigate the effect of negative experiences on the publishing productivity of academic mothers.

Considering the need to interpret and scrutinize a social phenomenon, a qualitative research method was employed while a phenomenological pattern was used, since the focal point was the experiences of the participants. In this phenomenological study, the object was 
to understand the experiences and perceptions of the participants with regard to work-life balance during the Covid-19 epidemic. The population of the research consisted of academic mothers who were employed at both the public and private universities in Turkey. The sample was created by a purposeful sampling method.

Within the scope of the research, 20 academic mothers, including 2 professors, 12 associate professors, and 6 Ph.D. lecturers working at both public and private universities were interviewed. Findings obtained from the study show that conducting research and publishing is difficult for academic mothers. Especially, it is observed that the substantial increase in inequalities in household chores and child care hinder the productivity of academic mothers and cause them to experience academic inefficiency. It can be stated that, due to all of their ongoing responsibilities, academic mothers do not have sufficient time to conduct research. In addition, they focus on their family lives by compromising their publishing performance. During the Covid-19 epidemic, academic mothers also stated that they felt guilty because they could not take care of their children when they tried to focus on their research.

Academic mothers participating in the study emphasize that partner support is limited. Preparing meals, supporting children for their lessons and homework, and ensuring the hygiene of the house are added to their ongoing responsibilities. For this reason, academic mothers are seen to start the day early, neglecting personal needs and hobbies. There is a work-life experience that increases their inner-conflict, feelings of guilt, and anxiety, and in turn decreases their publishing productivity.

In light of the findings, there are some suggestions to prevent academic mothers from the outcomes of gender inequalities in the Covid-19 epidemic period. Accordingly, it was seen that in some universities, trainings were organized to make distance education much more efficient. It is thought that these trainings would be useful in order to increase the quality of the education due to the different dynamics of distance education compared to face-to-face education. It may be suggested that universities might provide work-life balance trainings as well. In addition, universities might evaluate academic productivity by considering the gender equality issues.

Anahtar Kelimeler: Covid-19, akademisyen anneler, iş-yaşam dengesi, cinsiyet eşitsizliği, kariyer

Keywords: Covid-19, academic mothers, work-life balance, gender inequality, career 


\section{Giriş}

Dünya üzerinde ilk Covid-19 vakasına, Aralık 2019'da rastlanmıştır. Covid-19, yüksek bulaşma oranıyla kısa sürede korkulan bir hastalık haline gelmiştir (Shin, vd., 2020: 646). Türkiye'deki ilk Covid-19 vakası ise 10 Mart 2020 tarihinde tespit edilmiştir. Hastalığın yayılmasını önlemek, kamu sağlığını korumak için ülkemizde sosyal mesafe ve sosyal izolasyonun sağlanması yönünde çeşitli tedbirler uygulamaya konulmuştur. Söz konusu tedbirlere ilk ve orta öğretimin uzaktan gerçekleştirilmesi, üniversitelerin eğitimöğretim faaliyetlerini uzaktan sürdürmesi, altmış beş yaş üstü ve yirmi yaş altına getirilen sokağa çıkma kısıtlamaları, hafta sonları sokağa çıkma kısıtlamaları örnek olarak gösterilebilir. Covid-19'un mutasyona uğramasıyla artan bulaşıcılık hızını azaltmak için 13 Nisan 2021 tarihinde yayınlanan genelge ile ülke genelinde iki haftalık kısmi kapanma gerçekleşirken, 26 Nisan 2021 tarihinde yayınlanan genelge ile de 29 Nisan-17 Mayıs 2021 tarihleri arasında tam kapanma sürecine girilmiştir https:/www.icisleri.gov.tr/81-ilvaliligine-tam-kapanma-tedbirleri-genelgesi-gonderildi).

Covid-19 salgınının, söz konusu gelişmelerden de anlaşılacağı üzere sadece halk sağlığını tehdit etmekle kalmadığı görülmektedir. Salgın, aynı zamanda hayatın günlük akışı içinde gerek ekonomik gerekse sosyal açıdan toplumun her kesimini etkilemektedir (Cui, Ding ve Zhu, 2020:1). Covid-19 salgınının, derin ve sarsıcı etkilerinin gözlemlendiği bir diğer konu ise cinsiyet eşitsizliğidir (Oleschuk, 2020:1). Dünya geneline bakıldığında; sosyal mesafe ve sosyal izolasyonun sağlanması için başvurulan yöntemlerden biri olan uzaktan çalışmanın beraberinde getirdiği çocuk bakımı ile ev işlerinin, yüksek eğitim seviyesine sahip ve çift kariyerli eşler arasında bile eşit bir şekilde dağılmadığı görülmektedir (Pinho-Gomes, Peters, Thompson, Hockham, Ripullone, Woodward ve Cracel, 2020:1). Bu bağlamda cinsiyet eşitliğini sağlama konusunda öncü sayılabilecek İskandinav ülkelerinde dahi çalışan annelerin, karantina sırasında çocuk bakımı ve ev işlerinde eşlerine kıyasla orantısız bir yük üstlenmiş olduğu belirtilmektedir (Manzo ve Minello, 2020:120; 
Minello, 2020:2). Aslında çocuk bakımı ve ev işlerinde orantısız bir dağılım salgın öncesinde de mevcut olmakla birlikte okul, kreş, ev içinde yardımcı (bakıcı ve temizlikçi) desteğiyle ev içi yüklerin bir nebze azaldığı ifade edilmektedir (O'Reilly, 2020:7). Salgınla birlikte söz konusu destek mekanizmalarını kaybeden çalışan annelerin kısa ve uzun vadede kariyerlerine ilişkin birtakım olumsuzluklarla karşılaşmalarının olası olduğu öngörülmektedir (Nash ve Churchill, 2020:2).

Ülkemizde Covid-19 salgını ile kamuda dönüşümlü ve uzaktan çalışmaya geçildiği (https://www.icisleri.gov.tr/81-il-valiligine-tamkapanma-tedbirleri-genelgesi-gonderildi), özel sektörde ise çoğu işletmenin uzaktan çalışmayı benimsediği görülmektedir (ILO, 2021). Benzer bir durumun, üniversitelerin eğitim-öğretim faaliyetlerini uzaktan sürdürmeleri doğrultusunda üniversitede görev yapan akademisyenler açısından da geçerli hale geldiği ifade edilebilir. Söz konusu bağlamda bu çalışma, çalışan annelerin özel bir grubunu oluşturan "akademisyen annelerin" Covid-19 salgını döneminde işyaşam dengelerinde ve kariyerlerinde yaşadıkları sorunları araştırmayı amaçlamaktadır. Nitel araştırma yönteminin benimsendiği bu çalışmada, Türkiye'de devlet ve vakıf üniversitelerinde öğretim üyesi statüsünde çalışan akademisyen annelerle derinlemesine görüşmeler gerçekleştirilerek hem Covid-19 salgını döneminde akademisyen annelerin yaşam ve çalışma deneyimlerinin anlaşılması amaçlanmış hem de bu dönemden kariyer ilerlemeleri açısından dezavantajlı çıkmamaları için alınabilecek önlemler sunulmaya çalışılmıştır.

Çalışmada, akademisyen annelere odaklanılmasının üç temel nedeni bulunmaktadır. İlk olarak; ülkemizde üniversitelerde salgının yayılmasını önlemek amacıyla uzaktan eğitim kararı alınmıştır. Bu kararla birlikte akademisyenlerin verdikleri dersler, yapacakları sınavlar, jüri üyelikleri vb. faaliyetler online platformlara taşınmıştır. Dolayısıyla akademisyen anneler, uzaktan çalışmayı deneyimleyen grup içinde yer almaktadır. İkincisi, akademisyenlik eğitim-öğretim faaliyetlerinin yanı sıra araştırma faaliyetlerini 
de içeren bir meslektir. Üstelik araştırma faaliyetleri arasında yer alan yayın sayıları, akademisyenlerin atama ve yükseltme süreçlerinde kullanılan kritik bir başarı ve puanlama göstergesini oluşturmaktadır. Toplumsal cinsiyet rolleri nedeniyle ev içi iş yükünde yaşanan dengesizlikler, özellikle de tam zamanlı çocuk bakımının, akademisyen annelerin yayın yapma üretkenliklerini olumsuz yönde etkileyebileceği tahmin edilmektedir. Nitekim, kadın akademisyenlerin makale gönderme sayılarındaki düşüşü ile erkek akademisyenlerin yayın sayısındaki artışı tespit eden araştırmalar da bu durumu destekler niteliktedir (Andersen, Nielsen, Simone, Lewiss ve Jagsi, 2020:1). Konunun sadece makale gönderim sayısı, yayın sayısı vb. üzerinden açıklanamayacağı ve anlaşılması gereken farklı boyutların da olabileceği düşüncesinden hareketle, içinden geçtiğimiz dönemde bu konunun incelenmesi önemli görülmektedir. Akademisyen annelerin Covid-19 salgını döneminde çalışma ve yaşam deneyimlerinin anlaşılmaya çalışıldığı bu çalışma üç bölümden oluşmaktadır. İlk olarak konunun anlaşılması açısından kavramsal çerçeve sunulmuştur. İkinci bölümde 20 akademisyen anneyle yapılan görüşmelerden elde edilen verilerin analizi sonucu elde edilen bulgular paylaşılmış, okuyucuya kolaylık sağlanması açısından görselleştirilmiştir. Son bölümde ise tartışılmıştır.

\section{Kavramsal Çerçeve}

\section{Akademide İş-Yaşam Dengesi ve Akademisyen Anneler}

Akademide iş-yaşam dengesi üzerine yapılan nitel çalışmaların iki ana yaklaşım benimsediği gözlemlenmektedir. İlk yaklaşım (Forster, 2000; Woodward, 2007), iş-yaşam dengesinin kurulması sırasında oluşan çatışma ve gerginlikleri ortaya koyan deneyim araştırmalarını içermektedir. İkinci yaklaşım ise üniversitelerde iş-yaşam dengesinin oluşturulup korunabilmesi için yürürlüğe konan politika ve prosedürlerin değerlendirildiği çalışmalardan oluşmaktadır (Bkz. Spalter-Roth ve Erskine, 2005; Waters ve Bardoel, 2006). Buna göre ilk grup çalışmalar bireysel analiz seviyesini benimserken, ikinci grup çalışmalar kurumsal analiz seviyesini 
benimsemektedir. Ancak her iki yaklaşım da iş-yaşam dengesinde cinsiyeti temel faktör olarak kabul etmekte; cinsiyetin sosyal yaşamın inşası ve iş-yaşam dengesi üzerindeki etkilerini kuramsal bir bakış açısıyla irdelemektedir.

İş-yaşam dengesi literatürünün yanı sıra kariyer literatüründe de cinsiyetin temel bir faktör olduğu kabul edilmektedir. Buna göre kariyer literatüründe, kadınların iş ve aile sorumlulukları nedeniyle özel bir kariyer grubu olarak ele alınıp ayrı bir şekilde incelenmesi yönünde birtakım tartışmaların olduğu dikkat çekmektedir (Patton ve McMahon, 2006:154; Sullivan, 1999:461). Kadınların hamilelik, doğum izni, çocuk bakımı ve ev işleri vb. nedeniyle iş-aile dengesini sağlamada sorun yaşayabildikleri, bu durumun da kariyerlerini etkileyebildiği gözlemlenmektedir (Buzzanell vd., 2005:262).

Kadın akademisyenler açısından ele alındığında, özellikle üniversitelerin neoliberalleşmesi ve prekarizasyonu sonucunda başarılı bir akademik kariyere sahip olmanın kadınlar açısından beraberinde çeşitli fedakârlıkları getirdiği ileri sürülmektedir (Ivancheva, Lynch ve Keating, 2018). Literatür incelendiğinde, ideal akademisyenin son derece üretken, kariyer odaklı, gerektiğinde mobil olabilecek, 7/24 erişilebilir ve çocuk bakım sorumluluklarından muaf olan akademisyen şeklinde tanımlandığı dikkat çekmektedir (Acker, 1992; Herschberg, Benschop ve van den Brink, 2018; Ivancheva, vd., 2018). Bu tanım, çalışma yaşamına hâkim olan "erillik” normunun akademiye de yansıdığını göstermekte ve ideal akademisyenin eril nitelikler taşıması gerektiğini vurgulamaktadır (Ivancheva vd., 2018). Yapılan ampirik araştırmalar, kadın akademisyenlerin ideal akademisyen tanımına uyma ve akademideki prekarizasyona ilişkin endişeleri nedeniyle doktora ve doçentlik çalışmalarına engel olmaması için anne olma kararlarını erteleyebildiklerini göstermektedir. Buna göre akademik çalışmalarında en verimli ve en üretken dönemlerinin doğurganlık yaşlarına denk gelmesinin, kadın akademisyenlerde bir tedirginlik yarattığı belirtilmektedir (Sutherland, 1985). Sommerkorn (1996) ise akademisyen annelerin çocuk bakımı 
ve ev işleri konusunda tıpkı çalışmayan kadınlar gibi merkezi bir sorumluluk üstlendiğini vurgulamaktadır. Buna göre kreş, aile içi destek, eş yardımı vb. gibi destek mekanizmalarının olduğu durumlarda bile sorumlulukların yine anne üzerinde yoğunlaştığını ifade etmektedir. Örneğin; hastalanan çocuğun bakımı için işten izin alan, çocuğu okuldan alıp eve getirmek için işten erken çıkmak zorunda kalan ebeveynin, genellikle akademisyen anne olduğu görülmektedir (Nikunen, 2012; Santos ve Cabral-Cardoso, 2008).

Akademik kariyer, her ne kadar zaman esnekliği sayesinde kadınlar için uygun bir kariyer gibi görünse de aslında zaman esnekliğinden uzaktır (Nash ve Churchill, 2020:5). Diğer bir deyişle akademide gece-gündüz fark etmeksizin devam eden çalışma saatleriyle araştırma ve akademik yayın yapma faaliyetlerinin zaman ve mekândan bağımsız aktığı görülmektedir (Currie, Harris ve Thiele, 2000). Cummins (2005) bu durumu, 'sınırsız adanma' ile açıklamakta ve sınırsız adanmanın iş-yaşam dengesinde 'kaosa' neden olduğunu ifade etmektedir. İş-yaşam dengesi kurma konusunda temel sorun da bu noktada başlamaktadır. Sınırsız ve süresiz olarak, ev yaşamına taşınan akademik çalışmalarla aile yaşamından doğan sorumluluklar, zaman ve enerjiyi paylaşma konusunda rekabet etmektedir. Kahn vd.'ne (1964) göre bireyin iş rolleriyle aile içindeki rollerinin çelişmesi rol çatışmasını doğurmaktadır. İş-aile çatışması; zaman, gerginlik ve davranış temelli olmak üzere üç şekilde ortaya çıkmaktadır.

İlk olarak zaman temelli çatışma ele alındığında, çoklu rollerin bireyin iş-aile konularına ayırdığı zaman açısından rekabete neden olacağı belirtilmektedir. Buna göre bireyin birden fazla rolü, zamanı için rekabet etmektedir. Zaman temelli çatışmalarda, uzun ve esnek olmayan iş saatleri veya işin eve taşınması gibi faktörler ön plana çıkmaktadır. Bu çatışmanın aileye bağlı nedenlerine küçük çocuk sahibi olma, ailede başkalarından sorumlu olma, büyük bir aileye sahip olma veya çift kariyerli eşler örnek olarak gösterilebilir (Barnes, Wagner ve Ghumman, 2012:792; Kahn vd., 1964; Steiber, 2009:472). 
Gerginlik temelli çatışma, bireyin bir rolü yerine getirme sürecinde yaşadığı gerginlik diğer rolüne yansıdığı zaman ortaya çımaktadır. Bireyin rol belirsizliği, örgütün sosyal desteğinin düşük olması veya hiç olmaması ve bireyin kariyer gelişimi sorunları, gerginlik temelli çatışmaya neden olabilmektedir (Steiber, 2009:471). Davranış temelli çatışma ise rollerden birinin öngördüğü davranışların, bireyin diğer roldeki davranış beklentileriyle örtüşmemesi olarak tanımlanmaktadır (Greenhaus ve Beutell, 1985). Bireyin aile ve iş yaşamında üstlendiği roller arasındaki zıtlıklar nedeniyle ortaya çıkan çatışma sonucundaki rollerden biri, diğerinin gerçekleşmesini zorlaştırabilmektedir (Edwards ve Rothbard, 2000).

\section{Covid-19 Salgını ve Cinsiyet Eşitsizliği}

Çeşitli araştırmacılar (Lewis, 2020; Nash ve Churchill, 2020:1; Manzo ve Minello, 2020:122), Covid-19 salgınının cinsiyet eşitsizliğini körükleyici bir etkisinin olduğunu iddia etmektedir. Hatta salginın beraberinde getirdiği sosyal izolasyonun, şimdiye kadar cinsiyet eşitliğinde kaydedilen ilerlemeyi durduracağı ve gerilemesine neden olacağı da ileri sürülmektedir (O’Reilly, 20208). Aslında dünya tarihinde farklı zamanlarda pek çok salgın yaşanmıştır. Yakın zamanda yaşanan salginlar incelendiğinde, Afrika ülkelerinde 2014 yılında ortaya çıkan Ebola krizi, 2015-2016 yıllarında yaşanan Zika, devam eden ylllarda meydana gelen SARS ve Domuz gribi gibi salginlar görülmektedir (Lewis, 2020). Yapılan araştırmalarda, söz konusu salgınların cinsiyet eşitliğine derin ve uzun süreli etkilerinin bulunduğu tespit edilmiştir. Örneğin; çocuklar Domuz gribine yakalandığında işten izin alıp çocuklarına bakmak durumunda kalanlar kadınlar olmuştur. Covid-19 salgınının ise yakın zamanda yaşanan bu salginlardan farklı olarak hem dünya genelini etkilemesi hem de beraberinde sosyal izolasyonu da getirmesiyle çalışan anneleri daha sarsıcı bir şekilde etkilediği ileri sürülebilir (Lewis, 2020).

Yaşanan Covid-19 salgınına kadar çift kariyerli eşler ${ }^{1}$ arasında ev işleri ve çocuk bakımı konusunda halihazırda bir eşitsizlik -............

1 Çift kariyerli eşler: Eşlerin her ikisinin de kariyer sahibi olmasını niteleyen bir kavramdır. 
bulunduğu; kabul gören toplumsal roller gereği kadınların erkeklere göre çocuk bakımı ve ev işleri rollerini daha fazla yüklendiği (Coltrane, 2004:216; Lundberg ve Rose, 2002:251), bu nedenle kariyerlerinde başarılı olabilmek için daha fazla çabaladıkları bilinmektedir. Söz konusu yüklere rağmen okul, kreş, çocukların açık havada katıldıkları etkinlikler (örneğin: parkta arkadaşlarla oyun oynama vb.), bakım verenler veya ülkemizde çocuk bakımında sıklıkla başvurulan aile büyüğü gibi destek mekanizmalarıyla çalışan annelerin çocuk bakımı konusunda destek alabildikleri ifade edilmektedir (O’Reilly, 2020:8). Ev işleri açısından incelendiğinde ise çalışan annelerin ev işlerine yardımcı desteğine sahip olabildikleri, zaman zaman dışarıda yemek yeme gibi aktivitelerle evdeki iş yüklerini hafifletebildikleri belirtilmektedir. Salgınla birlikte sosyal izolasyonun ve hijyenin sağlanması gayreti; okul ve kreşlerin kapatılması, bakıcı ve yardımcı desteğinin azalması gibi durumlar ev içi sorumlulukların da artmasına neden olmuştur. Aslında çalışan annelerin eşleri, ortak sorumluluk paylaşan kişiler olarak önemlidir. Nitekim Hauser (2012) toplumdaki cinsiyet eşitliğinin esas olarak evde eşler arasındaki rol dağılımıyla başladığını ifade etmektedir. Ancak cinsiyet eşitliğini sağlama konusunda öncü sayılabilecek İskandinav ülkelerinde dahi çalışan annelerin, karantina sırasında çocuk bakımı ve ev işlerinde eşlerine kıyasla orantısız bir yük üstlenmiş olduğu belirtilmektedir (Manzo ve Minello, 2020:120; Minello, 2020:2). Diğer bir destek mekanizması olan aile büyüklerine (örneğin: anneanne, babaanne, dede) erişim ise salgında yaşlı nüfusun yüksek risk grubunda olduğunun tespit edilmesiyle ülkemizde altmış beş yaş üstüne getirilen sokağa çıkma kısıtlamaları nedeniyle ortadan kalkmıştır. Yirmi yaş altına gelen sokağa çıkma yasaklarıyla çocukların parklara vb. alanlara götürülmesi de mümkün olamamıştır. Tüm bunlar doğrultusunda, çalışan annelerin destek mekanizmalarının ortadan kalkarak ev içindeki görev ve sorumluluklarına yenilerinin eklendiği gözlemlenmektedir. Söz konusu yeni görev ve sorumluluklara, çocukların okul eğitimlerine destek olmak (uzaktan eğitim), çocukları eğlendirmek, ev temizliği, aile bireylerinin tüm gün evde olmasıyla birlikte evde hazırlanan öğünlerin sayısındaki artış vb. örnek olarak gösterilebilir. Salgının beraberinde 
getirdiği bu tip görev ve sorumluluk artışının, cinsiyet eşitsizliğini derinleştirerek sadece ülkemizde değil dünya genelinde de çalışan anneleri derinden etkileyebileceği tahmin edilmektedir.

\section{Covid-19 Salgını ve Akademisyen Anneler}

Covid-19 salgınının, hayatın tüm akışını alt üst ettiği gibi üniversiteleri de çarpıcı bir şekilde etkilediği görülmektedir (Nash ve Churchill, 2020:2). Yüz yüze devam eden eğitim-öğretim sistemi uzaktan eğitim-öğretim sistemine dönüştürülmüş, böylelikle akademisyenlerin verdikleri lisans ve lisansüstü dersler, yaptıkları sınavlar, jüri üyelikleri vb. faaliyetler online platformlara taşınmıştır. Söz konusu değişiklikle birlikte akademisyenler, tüm bu eğitimöğretim faaliyetlerini ev ortamında yürütmek durumunda kalmışlardır. Eğitim-öğretim faaliyetlerinin yanı sıra akademisyenlerin yürütmekte olduğu araştırma faaliyetlerinin de eve taşındığı ifade edilebilir. Özellikle atama ve yükseltmelerde kritik başarı göstergesi olarak kullanılan makale, bildiri, kitap, kitap bölümü yazma ve projelerde çalışma gibi faaliyetlerinin de evden gerçekleştirilmesi gerekmiştir. Bu noktada "salgının beraberinde getirdiği sosyal izolasyon nedeniyle artan ev içi iş yükünden tüm akademisyenler eşit olarak mı etkilendiler?" sorusunun sorulması gerekmektedir.

Örneğin; British Journal for Philosophy of Science dergisi editörü Dr. Elizabeth Hannon, kadınlardan gelen makale sayısında çarpıcı bir düşüş olduğunu belirtmektedir. Benzer şekilde Comparative Political Science yardımcı editörü David Smuels de Nisan 2020'de erkeklerin dergiye gönderdiği makale sayısında \%50 artış olduğunu saptamıştır. Editörlerin söz konusu saptamalarının yanı sıra cinsiyete göre yayın sayılarının nasıl farklılaştığına dair yapılan çalışmalara da rastlanmaktadır. Örneğin; Andersen vd. (2020:1) tıp literatürüne odaklandıkları araştırmalarında, tıp alanındaki bir dergide 2019 ve 2020 yıllarında yapılan makaleleri incelemişlerdir. Bu çalışmada, ilk yazarı kadın olan makale sayısının 2020 yılında 2019 yılına kıyasla \%19 azaldığı tespit edilerek kadın akademisyenlerin üretkenliklerinin düştüğ̈ saptanmıştır. Söz konusu 
araştırmaların cinsiyete göre yayın sayısı üzerinden gittiği düşünüldüğünde, kadın akademisyenlerin anne olanlar ve olmayanlar arasında bir ayrım yapılamadığı gözlemlenmektedir. Ancak salgın sonrasında özellikle anne olan akademisyenlerin, çocuk bakımı ve ev işlerindeki artan yükleri neticesinde daha olumsuz sonuçlara maruz kalabilecekleri düşünülmektedir.

Bilimsel araştırma yürütmek, odaklanma ve yaratıcı düşünmeye bağlı olduğundan genellikle sessiz ve dikkati dağıtan unsurlardan uzak bir ortam gerektirmektedir (Cui, Ding ve Zhu, 2020:4). Örneğin; Prof. Dr. Joshua Gans, salgının ekonomi üzerindeki etkilerine odaklandığı kitabını biri ergenlik diğeri üniversite yaşındaki iki çocuğuyla birlikte karantina esnasında on dokuz günde yazdığını belirtmiş ve kitabın önsözünde sadece çok fazla düşündüğü için yaşadığı zihinsel yorgunluktan dert yanmıştır (Nash ve Churchill, 2020:2). Erkek akademisyenlerin araştırmalarını yürütebilmek için bulabildikleri sessiz ve kesintisiz ortamı, akademisyen annelerin artan ev içi sorumluluklarıyla bulup bulamadıkları ise şüphelidir (Cui, Ding ve Zhu, 2020:4). Gerek Prof. Dr. Joshua Gans örneği gerek editörlerin açıklamaları gerekse yayın sayılarıyla ilgili yapılan araştırmalar, halen salgının etkisindeki büyük resmi görebilmek için erken olsa da salgının toplumsal cinsiyet rolleri bağlamında akademideki cinsiyet eşitsizliğiyle ilgili ön bilgi vermektedir. Söz konusu ön bilgiler, salgınla birlikte akademide uzaktan çalışan erkek akademisyenlerin yayın sayılarında artış olduğunu gösterirken, kadın akademisyenlerin özellikle de anne olanların ev içi iş yükünde karşılaştıkları dengesizliklerle yayın yapma üretkenliklerinin azaldığını düşündürmektedir.

\section{Araştırmanın Yöntemi}

Bu çalışma, Covid-19 salgını nedeniyle üniversitelerdeki eğitim-öğretim faaliyetlerinin online platformlara taşınmasının, akademisyen annelerin zaman, gerginlik ve davranış temelli çatışmaları daha sık ve yoğun yaşamalarına neden olabileceği düşüncesinden hareket edilerek yapılmıştır. Bilindiği üzere yayın sayıları akademik atama ve yükseltmelerde kritik bir başarı göstergesi olarak 
kabul edilmektedir. Bu bağlamda söz konusu olumsuz deneyimlerin akademisyen annelerin verimliliği üzerinde yaratacağı etkiyi araştırmanın önemli olduğu düşünülmektedir.

Yukarıda ifade edilen deneyimleri araştırmak üzere yapılan çalışmada nitel araştırma yöntemi ve olgu bilim deseni benimsenmiştir. Nitel araştırmalar öznel anlayış gereği, ayrıntılı bir biçimde bütünsel verilere odaklanmaktadırlar. Burada temel amaç; insanların yaşam biçimlerini, kendilerine ait öykülerini, deneyimlerini, davranışlarını, örgütsel yapı ve toplumsal değişmeyi anlama çabasıdır (Strauss ve Corbin, 1990). Olgu bilim ise bir olguyu deneyimleyen tüm katılımcıların ortak özelliklerini tanımlamaya odaklanmaktadır. Söz konusu olgular, yaşam içindeki olaylar, algılar, kavramlar, yönelimler, durumlar ve deneyimler şeklinde ortaya çıkabilmektedir. Buradaki temel nokta, bir olguyu deneyimleyen tüm katılımcıların ortak özelliklerini tanımlama çabasıdır. Araştırmacılar söz konusu olguyla ilgili deneyime sahip bireylerden veri elde ederler ve bütün bireylerin deneyimlerinin özünü tanımlayan bütüncül bir betimleme yapmaya çalışırlar (Cresswell, 2018:77). Bu nedenle nitel araştırmalarda örnekler, belirli bir çalışmanın amacına ne kadar iyi hizmet ettiğiyle ölçülür. Diğer bir deyişle araştırmacı, örnekleme kararını verirken sistematik ve rasyonel nedenler belirlemelidir. Örneğin bireyleri veya grup üyelerini (kimleri örneklemeli), zamanı, bağlamı (örneklemi) ve yeri (örneklenecek yeri) seçmek zorundadır. Bununla birlikte nitel araştırmalardaki bir örneklemde insan, zaman veya yer gibi örneklem birimlerine dikkat etmek gerekir. Çünkü nitel araştırmalarda örneklemin ölçüt temelli olması gerekmektedir (Yağar ve Dökme, 2018:4). Örnekleme yöntemleri olasılıklı ve amaçlı örnekleme olmak üzere iki temel sınıfta toplanabilir. Nitel çalışmalarda ağırlıklı olarak amaçlı örnekleme yöntemleri kullanılmaktadır. Bunun nedeni örneklem seçiminin, evreni temsil etme derecesinden ziyade araştırma konusuna uygunluğudur (Baltacı, 2018; Sandelowski, 1986).

Amaçlı örnekleme, sınırlı kaynakların en etkin kullanımı için bilgi bakımından zengin vakaların belirlenmesi ve seçilmesi 
için nitel araştırmalarda yaygın olarak kullanılan bir tekniktir. Bu örnekleme yöntemi, ilgilenilen konu hakkında bilgili ve deneyimli bireylerin ya da grupların tanımlanması ve seçilmesini içerir (Yağar ve Dökme, 2018:4). Çalışmada, benimsenen yöntem ve desene uygun olarak amaçlı örneklem yöntemi benimsenmiştir. Nitekim amaçlı örnekleme yöntemi, araştırmacının derinlemesine çalışmasına olanak vermektedir (Yıldırım ve Şimşek, 2018:118). Bu araştırmada temel amaç, Covid-19 salgını döneminde akademisyen annelerin iş-yaşam deneyimlerini anlamaktır. Bu amaç doğrultusunda araştırmaya katkı verecek katılımcıların bu bağlamda bir deneyime sahip olması ve söz konusu deneyimi paylaşması gerekmektedir. Çalışmayı özgün kılacak söz konusu gereklilik bu deneyime sahip katılımcıların seçilmesini gerekli kılmaktadır. Çalışmaya katkı veren 20 katılımcının ortak özelliği Yüksek Öğrenim Kurumu'na bağlı üniversitelerde, öğretim üyesi statüsünde çalışan ve en az bir çocuğu olan "akademisyen anne" olmalarıdır. Araştırma kapsamında, devlet ve vakıf üniversitelerinde öğretim üyesi statüsünde çalışan ikisi profesör, on ikisi doçent, altısı doktor öğretim üyesi olmak üzere yirmi akademisyen anneyle görüşülmüştür. Örneklemi oluşturan akademisyen annelerin yaşları 33-48 arasında; çocuklarının yaşları ise 1-16 arasında değişmektedir. Tablo 1'de akademisyen annelere ait bilgiler sunulmuştur.

Tablo 1: Akademisyen Annelere Ait Demografik Bilgiler

\begin{tabular}{|lccc|}
\hline & $\begin{array}{c}\text { Prof. } \\
\text { Dr. }\end{array}$ & $\begin{array}{c}\text { Doç. } \\
\text { Dr. }\end{array}$ & $\begin{array}{c}\text { Dr. } \\
\text { Öğgretim } \\
\text { Uyesi }\end{array}$ \\
Akademisyen Annelerin Medeni Durumu & & & \\
Evli Akademisyen Anneler & 2 & 11 & 5 \\
Bekar Akademisyen Anneler & 0 & 1 & 1 \\
$\begin{array}{l}\text { A Cocuk Sahibi Olan Akademisyen } \\
\text { Annelerin Unvan Dağılımı }\end{array}$ & 0 & 8 & 3 \\
$\begin{array}{l}\text { A̧ocuk Sahibi Olan Akademisyen } \\
\text { Annelerin Unvan Dağılmı }\end{array}$ & 2 & 4 & 3 \\
Toplam Öğretim Üyesi Sayısı & & & \\
\hline
\end{tabular}


Görüşmelere başlamadan önce İstanbul Üniversitesi Sosyal ve Beşeri Bilimler Etik Kurulu'na başvuruda bulunulmuş ve ilgili kuruldan 23 Ekim 2020 tarihinde gelen 183200 sayılı etik onay doğrultusunda görüşmelere başlanmıştır. Görüşmeler 25 Ekim-10 Kasım 2020 tarihleri arasında gerçekleştirilmiştir. Çalışmada yarı-yapılandırılmış görüşme formu kullanılmıştır. İçinde bulunulan salgın ortamı nedeniyle akademisyen annelerle yapılan görüşmeler telefon yoluyla gerçekleştirilmiştir. Her görüşme ortalama 2045 dakika sürmüştür. Görüşmeye başlamadan önce aydınlatılmış onam formu, katılımcıya sesli olarak okunmuş ve araştırmaya katıldıklarına dair sözlü onayları alınmıştır. Görüşmeler, katılımcıların onayı ile ses kayıt cihazı aracılığıyla kayıt altına alınmış, ayrıca görüşmeler sırasında araştırmacı tarafindan notlar tutulmuştur. Katılımcılarla yapılan görüşmeler, görüşme formu kullanılarak "amaçlı sohbet" şeklinde gerçekleştirilmiştir. Kapsamlı bilgi edinebilmek amacıyla katılımcılara açık uçlu sorular yöneltilmiştir (Sorular için bkz: Ek 1). Çalışmada kullanılan sorular, ilgili literatürden yola çıkılarak hazırlanmıştır (Toffoletti ve Starr, 2016; Forster, 2000; Magadley, 2019; Greenhaus ve Beutell, 1985; Santos ve Cabral-Cardoso, 2008; Hoskins, 2010; Şentürk, 2000; Başarır ve Sarı, 2015; Raburu, 2015).

Aşağıdaki tabloda görüşme sorularının tematik dağılımı bulunmaktadır:

Tablo 2: Görüşme soruları tematik dağılımı

\begin{tabular}{|l|l|}
\hline İş-Yaşam Dengesi & $\begin{array}{l}\text { Salgını beraberinde getirdiği uzaktan } \\
\text { eğitim öncesinde bir gününüzü nasıl } \\
\text { planlar ve geçirirdiniz? }\end{array}$ \\
\hline Salgın Döneminde İş -Yaşam Dengesi & $\begin{array}{l}\text { Salgının beraberinde getirdiği uzaktan } \\
\text { eğitim süresince bir gününüzü nasıl } \\
\text { planllyor ve geçiriyorsunuz? }\end{array}$ \\
\hline Çok Yönlü Sorumluluk ve Sıralaması & $\begin{array}{l}\text { Salgının beraberinde getirdiği uzaktan } \\
\text { eğitim sürecinde öncelikleriniz değişti } \\
\text { mi? Nasıl? }\end{array}$ \\
\hline $\begin{array}{l}\text { İş- Aile Çatışması Nedenlerinin } \\
\text { (Zaman, Davranış, Gerginlik Temelli } \\
\text { Nedenler) Belirlenmesi }\end{array}$ & $\begin{array}{l}\text { Salgının beraberinde getirdiği uzaktan } \\
\text { eğitim sürecince iş-yaşam dengesini } \\
\text { kurmakta zorlandığını oldu mu? Zor- } \\
\text { landığınız konular neler? }\end{array}$ \\
\hline
\end{tabular}




\begin{tabular}{|l|l|}
\hline $\begin{array}{l}\text { Sinır Bulanıklı̆̆, Suçluluk Hissi, } \\
\text { Yorgunluk Hissi }\end{array}$ & $\begin{array}{l}\text { Salğının beraberinde getirdiği uzaktan } \\
\text { eğitim süresince iş-yaşam dengesini } \\
\text { kurmakta zorlandığınız konulara nasıl } \\
\text { çözümler buldunuz? }\end{array}$ \\
\hline Akademik Verimlilik & $\begin{array}{l}\text { Uzaktan eğitime geçilmesi, akademik } \\
\text { faaliyetlerinizdeki (örneğin: kitap, ki- } \\
\text { tap bölümü, makale, bildiri, araştırma } \\
\text { projesi yazımı vb.) üretkenliğinizi nasıl } \\
\text { etkiledi? }\end{array}$ \\
\hline Akademik Verimlilik & $\begin{array}{l}\text { Salginla birlikte geçilen uzaktan eği- } \\
\text { tim öncesi ve sonrası dönemleri karşı- } \\
\text { laştırdığınızda akademik çıtılarınızn } \\
\text { (örneğin: kitap, kitap bölümü, makale, } \\
\text { bildiri, araştırma projesi vb.) bir karşı- } \\
\text { laştırmasını yapar mısnnı? }\end{array}$ \\
\hline Akademisyen Anne & $\begin{array}{l}\text { Akademisyen bir anne olarak kendinizi } \\
\text { nasıl tanımlarsınız? }\end{array}$ \\
\hline
\end{tabular}

Görüşmelerden elde edilen ses kayıtları, sadece araştırmacılar tarafından bilinen bir şifre korumasıyla araştırmacıların kişisel bilgisayarlarında tutularak yine araştırmacılar tarafindan MS Office Word programına aktarılarak metin dosyaları haline getirilmiştir. Ses kayıtlarının metin dosyaları haline getirilmesini takiben ilgili ses kayıtları araştırmacıların kişisel bilgisayarlarından silinerek imha edilmiştir. Metin haline getirilen veriler belirlenmiş temalar eşliğinde kodlanmıştır. Görüşme verilerinin analiziyle elde edilen kodlar iş-aile çatışması, çok yönlü sorumluluk, sinır bulanıklığı, suçluluk hissi, yorgunluk hissi, akademik verimsizlik ve akademisyen anne olmak üzere yedi tema altında gruplandırılmıştır. Sürecin sistematik biçimde yönetilmesi için MAXQDA Plus 2020 programından yararlanılmıştır. Çalışmada MAXQDA Plus 2020 programının tercih edilmesinin nedeni, söz konusu programın görsel araçlar yardımıyla okuyucuya kolaylık sunması; araştırmacı tarafından belirlenen ve atanan kodlar eşliğinde belgelerin analiz edilmesi ve söz konusu analizlerin görselleştirilerek okuma ve yorumlama olanağ sağlamasıdır.

Çalışmanın geçerliliği için araştırmacı, ilgili literatürden hareketle soru listesi oluşturmuştur. Söz konusu soruların kapsam geçerliğine ve uygunluğuna yönelik olarak iki uzman görüşü alınmıştır. Uzmanlar; katılımcıların Covid-19 salgını sırasında 'akademisyen 
anne' olmayı tanımlamaları, amaçlı sohbet sırasında ihtiyaç duyulduğunda araştırmacının ilave sorular sorması konusunda hemfikir oldukları görülmüştür. Olgu bilim deseninin benimsendiği bir araştırmada en önemli konulardan biri katılımcıların araştırılan olguyla ilgili deneyimlere sahip olmaları ve söz konusu deneyimleri açık bir şekilde ifade edebilmeleridir. Bu çalışmada araştırılan olgu "Covid-19 salgını döneminde akademisyen annelerin iş-yaşam deneyimleri”dir. Her bir katılımcının karakteristik özellikleri, deneyimleri ve söz konusu deneyimleri aktarma biçimleri birbirinden farklı olacağından araştırma sırasında yarı-yapılandırılmış görüşme tercih edilmiştir. Böylelikle araştırmacı, gerektiğinde katılımcıya ek sorular sorarak deneyimler ve temalar hakkında daha fazla ortak nokta bulma ve kategoriler geliştirme noktasında bağlamsal bilgi sağlamış olacaktır. Çalışmada güvenirlik açısından verilerin ayrıntılı ve amaca uygun bir biçimde toplanması, araştırmada izlenen aşamaların açıkça belirtilmesi, araştırmacının araştırma konusu olguya ilişkin tarafsız durması (görüşmeye başlamadan önce katılımcıya sesli olarak okunan onam formu ile bilgi verilmiştir.), araştırmada veri kaynağı olan bireylerin açık şekilde tanımlanması, araştırma sürecinde oluşan sosyal olayların ve süreçlerin tanımlanması, kuramsal çerçevenin ve varsayımların tanımlanması, veri toplama ve analiz yöntemlerinin ayrıntılı olarak açıklanması sağlanmıştır (Yıldırım ve Şimşek, 2000). Ayrıca çalışmada kullanılan tematik kodlar da yine ayrı bir uzman tarafindan değerlendirilmiş, kod uyumu ve temsili konusunda fikir birliğine varılmıştır.

Katılımcıların gizliliğini sağlamak ve kimliklerini anonimleştirmek amacıyla her birine alfabetik sıra ile birer harf ataması yapılmıştır. Her bir ifadenin sonunda parantez içinde belirtilen harfler, söz konusu katılımcıyı bir diğerinden ayırmak için kullanılan harflerdir.

\section{Araştırmanın Bulguları}

$\mathrm{Bu}$ bölümde, araştırmadan elde edilen bulgular temalar altında sınıflandırılmıştır. Söz konusu temalar ve katılımcıların 
görüşleri, görsel şekiller eşliğinde sunulmakta ve ardından bulgular yorumlanarak tartışılmaktadır.

\section{Tema Modellemesi}

Araştırmanın bu bölümünde, akademisyen annelerle yapılan görüşmelerden kesitler aktarılmaktadır. Covid-19 salgınında akademisyen anne olma konusunda edinilen deneyimler ana temalar olarak tanımlanmakta, söz konusu deneyimleri etkileyen faktörler olduğunda bunlar da alt temalar olarak ifade edilmektedir. 


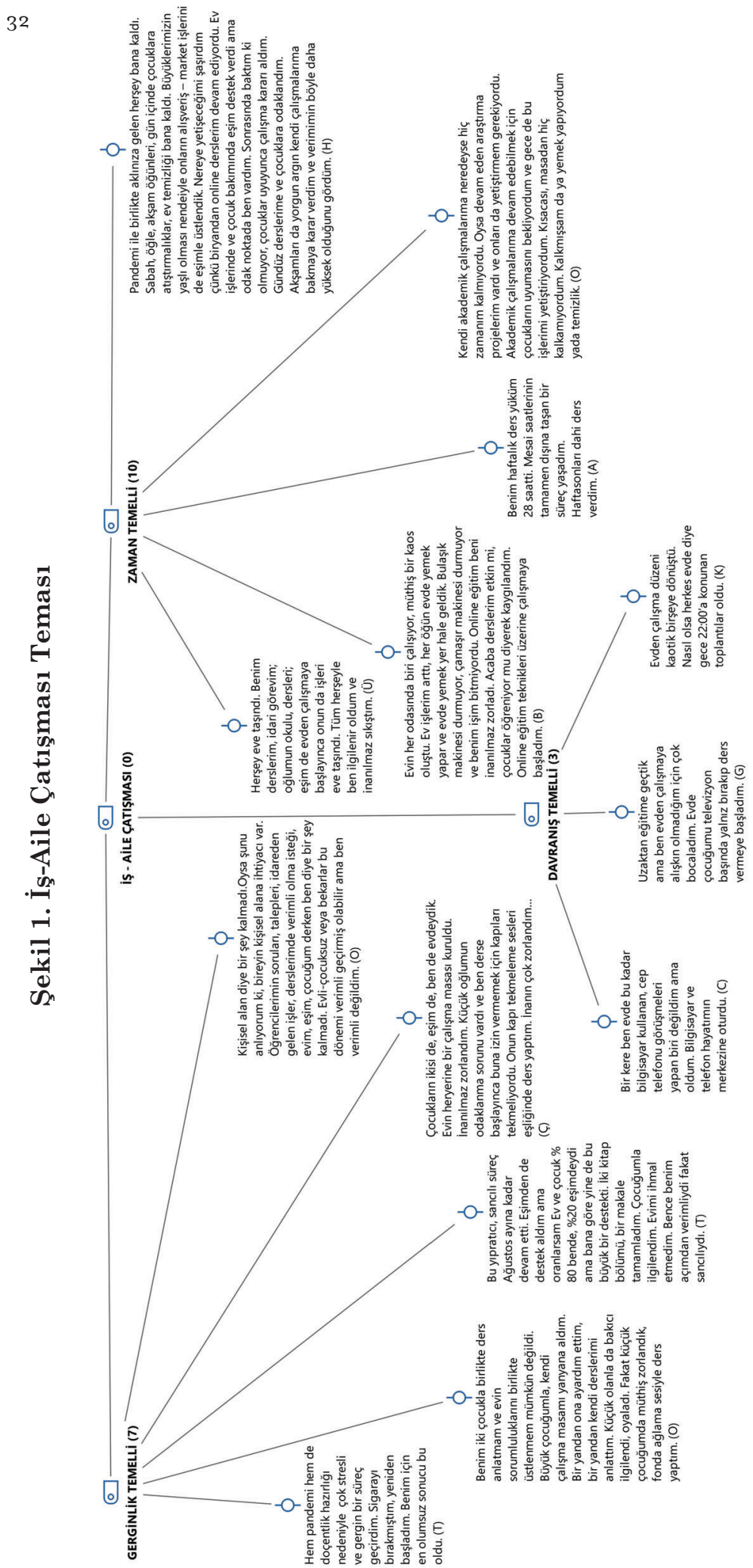




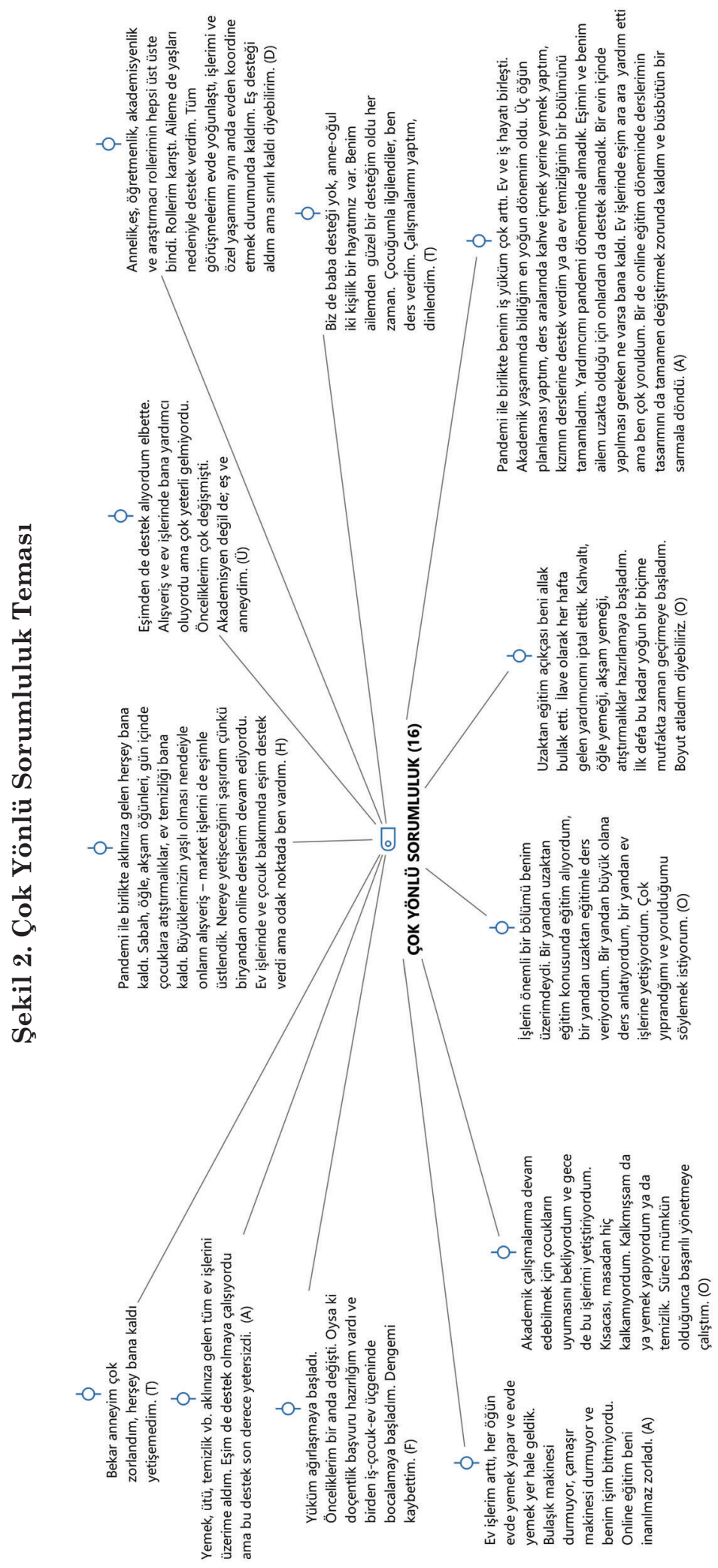




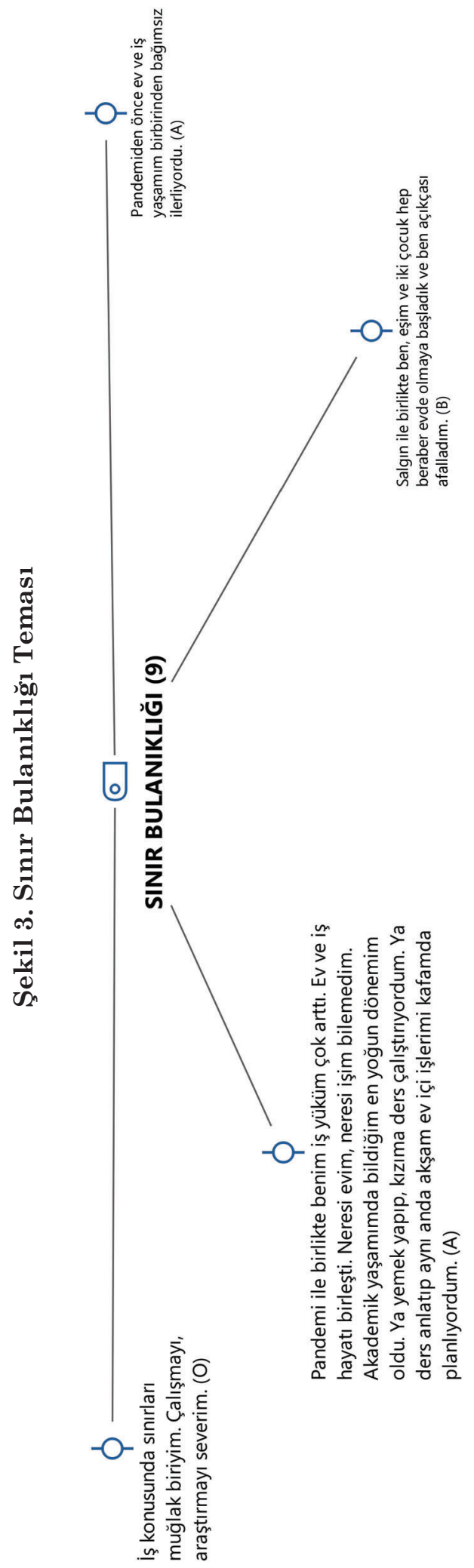




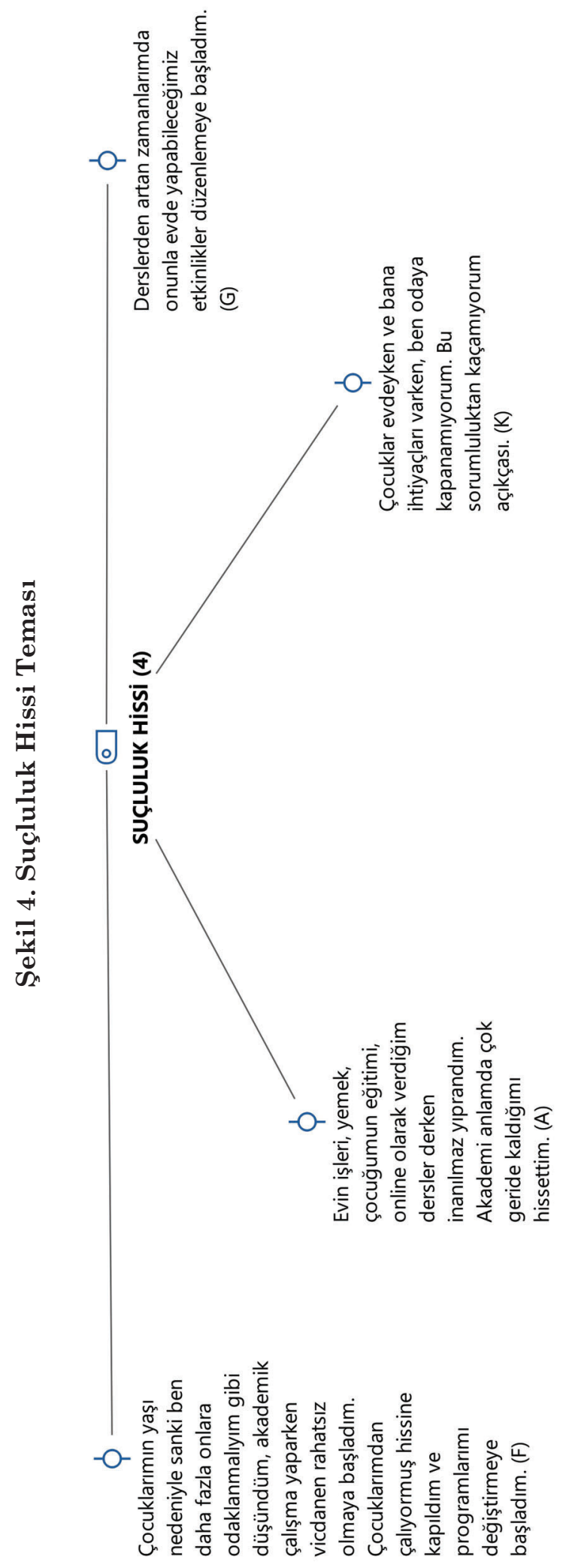




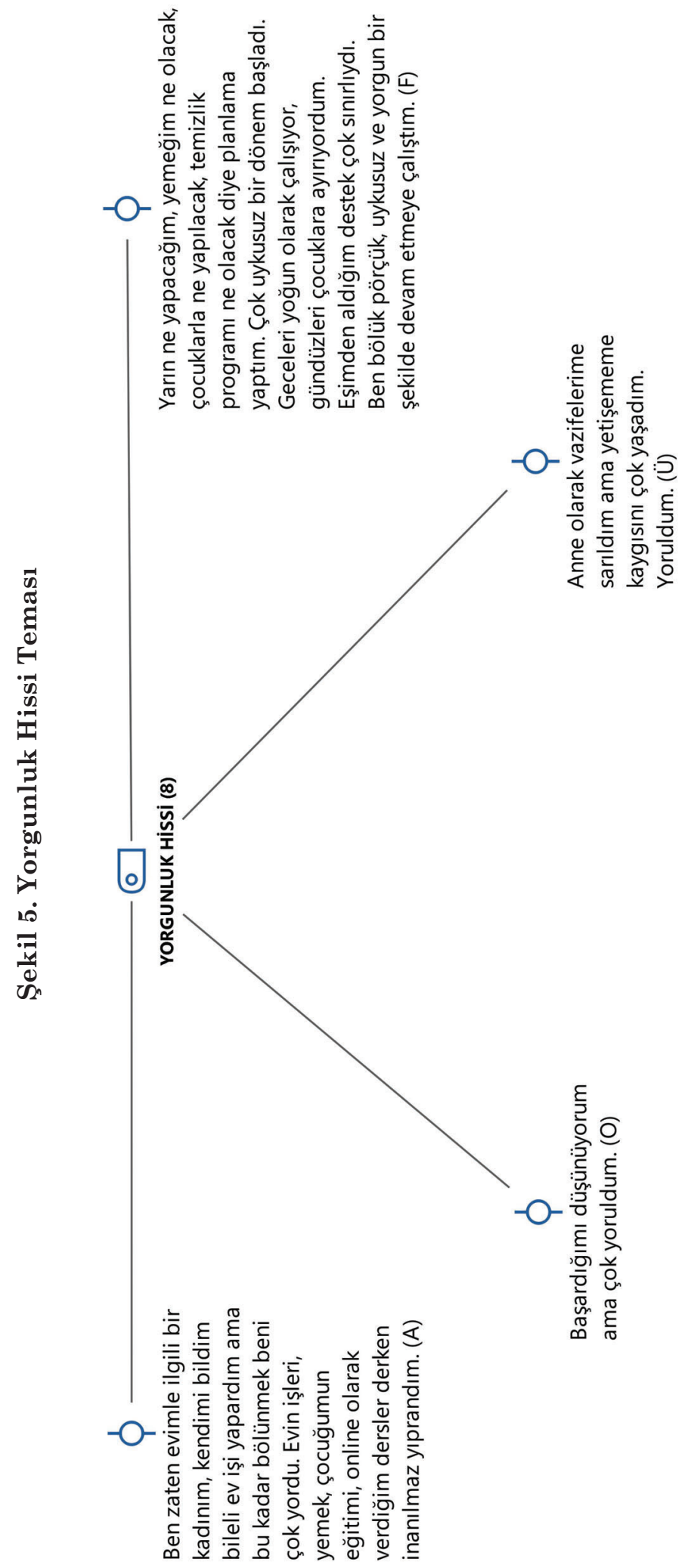




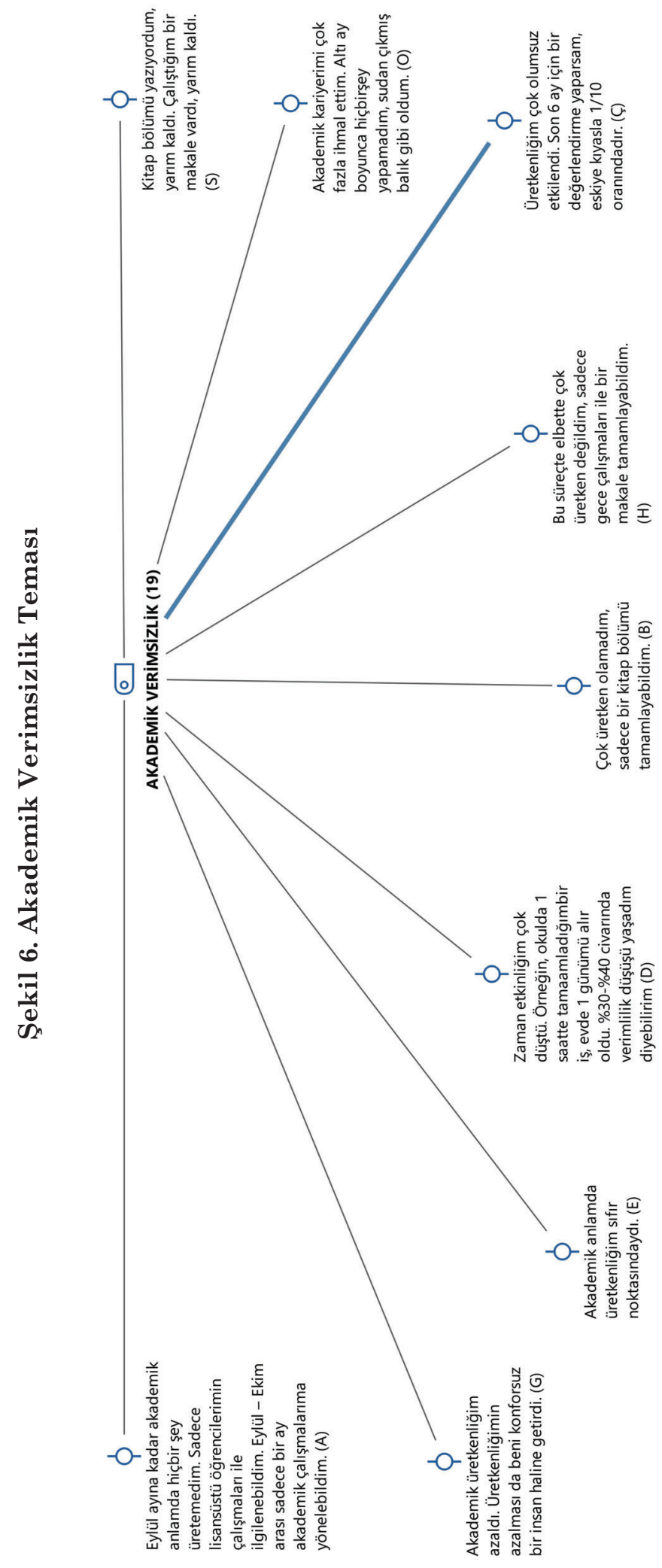




\section{Tema Modelleme Yorumlaması}

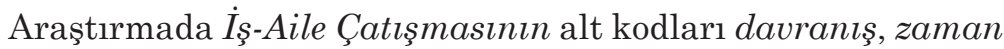
ve gerilim temelli çatışmalar olarak sinıflandırılmıştır. Söz konusu alt kodlar altında, katılımcıların deneyimlerine yer verilmiştir. Bununla birlikte sınır bulanıklığı, yorgunluk hissi, suçluluk hissi, akademik verimsizlik kodlarının alt kodu bulunmamaktadır. Söz konusu kodlar altında, akademisyen annelerin deneyimleri birebir paylaşılmaktadır.

İş-Aile Çatışması ana kodunun hemen yanında parantez içinde belirtilen sayısının (0) olması söz konusu ana kod altında kodlama yapılmadığının ancak alt kodlar altında zaman temelli (10), gerginlik temelli (7), davranış temelli (3) deneyim aktardığı şeklinde yorumlanmaktadır. Diğer bir deyişle söz konusu rakamlar, deneyimlerin frekanslarını yansitmaktadır. Dolayısıyla akademisyen annelerin zorlandıkları alanın başında iş-aile çatışması deneyiminin yer aldığını söylemek mümkündür. İlave olarak akademisyen anneler zaman konusunda kendilerini baskı altında hissetmekte ve yapılması gereken işlerini yerine getirme noktasında zaman çatışması yaşadıklarını ifade etmektedirler. Nitekim, "Pandemiyle birlikte aklınıza gelen her şey bana kaldı. Sabah, öğle, akşam öğünleri, gün içinde çocuklara atıştırmalıklar, ev temizliği bana kaldı. Büyüklerimizin yaşlı olması nedeniyle onların alışveriş - market işlerini de eşimle üstlendik. Nereye yetişeceğimi şaşırdım çünkü bir yandan online derslerim devam ediyordu. Ev işlerinde ve çocuk bakımında eşim destek verdi ama odak noktada ben vardım. (H)"ifadesi, zaman baskısını teyit eder niteliktedir. Zaman temelli çatışmanın temelinde ise çok yönlü sorumluluk yüklenme davranışı yer almaktadır.

Çalışmada ana kodlardan Çok Yönlü Sorumluluk kodu altında gösterilen deneyimlerin zaman çatışması yarattığı gözlemlenmektedir. "Pandemiyle birlikte benim iş yüküm çok arttr. Ev ve iş hayatı birleşti. Akademik yaşamımda bildiğim en yoğun dönemim oldu. Üç öğün planlaması yaptım, ders aralarında kahve içmek yerine yemek yaptım, kızımın derslerine destek verdim ya da ev 
temizliğinin bir bölümünü tamamladım. Yardımcımı pandemi döneminde almadık. Eşimin ailesi ve benim ailem uzakta olduğu için onlardan da destek alamadık. Bir evin içinde yapılmast gereken ne varsa bana kaldl. Ev işlerinde eşim ara ara yardım etti ama ben çok yoruldum. Bir de online eğitim döneminde derslerimin tasarımını da tamamen değiştirmek zorunda kaldım ve büsbütün bir sarmala döndü. (A)" söylemi akademisyen annenin çok yönlü sorumluluk noktasında yaşadığı çatışmayı ifade etmektedir. Anne, eş, bakıcı, aşçı, akademisyen olma rollerinin birleşimi çok yönlü sorumluluk kavramını beraberinde getirmektedir. "Annelik, eş, öğretmenlik, akademisyenlik ve araştırmact rollerimin hepsi üst üste bindi. Rollerim karıştı. Aileme de yaşları nedeniyle destek verdim. Tüm görüşmelerim evde yoğunlaştı, işlerimi ve özel yaşamımı aynı anda evden koordine etmek durumunda kaldım. Eş desteği aldım ama sinırlı kaldı diyebilirim. (D)" ifadesiyle söz konusu rolleri yerine getirmeye çalışan akademisyen anne, roller arası geçişte zorlanmaktadır.

Roller arası bu geçiş Sınır Bulanıklı̆̆ te ve hangi rolün nerede bitip diğer rolün nerede başladığını tespit etme sorun haline gelmektedir. Birçok sorumluluğu eş zamanlı olarak yerine getirmeye çalışan akademisyen anne; söz konusu sorumluluklarını yerine getirme noktasında kaygı ve tedirginlik hissetmektedir. Söz konusu kaygı ve tedirginlik; akademisyen annenin hem daha fazla yorulmasına hem de rolleri arasında eksik kalanların kaygısı ile suçluluk hissetmesine neden olmakta ve döngü pekişerek devam etmektedir.

Suçluluk Hissi kodu altında ifade edilen "Çocuklarımın yaşı nedeniyle sanki ben daha fazla onlara odaklanmalıyım gibi düşündüm, akademik çalışma yaparken vicdanen rahatsiz olmaya başladım. Çocuklarımdan çalıyormuş hissine kapıldım ve programlarımı değiştirmeye başladım. (F)" söylemi ile katılımcı çok yönlü sorumluluğun yarattığı suçluluk hissini ifade etmeye çalışmıştır. Bununla birlikte "çocuklar evdeyken ve bana ihtiyaçları varken, ben odaya kapanamıyorum. Bu sorumluluktan kaçamıyorum açıkçası." ifadesi de akademisyen annenin, anne ve akademisyen olma rolleri 
arasında seçim yaparken suçluluk hissettiğini destekler niteliktedir. "Başardığımı düşünüyorum ama çok yoruldum.” diye.

Çok yönlü sorumluluklar akademisyen annenin Yorgunluk Hissi'ni de arttırmaktadır. Katılımcılardan birinin "ben zaten evimle ilgili bir kadınım, kendimi bildim bileli ev işi yapardım ama bu kadar bölünmek beni yordu. Evimin işleri, yemek, çocuğumun eğitimi, online olarak verdiğim dersler derken inanılmaz yıprandım." ifadesi hem fiziksel hem de zihinsel yorgunluğu destekler niteliktedir.

Akademik Verimsizlik kodu altında paylaşılan deneyimler, çalışmaya katılan akademisyen anneler arasında Covid-19 salgını sırasında akademik çalışma yapamadığını ifade eden annelerin deneyimleridir. Çalışmada sadece dört akademisyen anne çalışma üretebildiğini ifade ederken, geriye kalan on altı akademisyen anne ise çalışmalarını tamamlayamadan erteleme kararı aldıklarını çeşitli biçimlerde aktarmışlardır. "Altı ay boyunca hiçbir şey yapamadım, sudan çıkmış balık gibi oldum. (O)” ifadesi, akademik üretkenliğinin durduğunu ifade eden akademisyen annelerden birine aittir. Öte yandan bir başka akademisyen anne "Lisansüstü öğrencilerimin çalışmaları, yeterlilik ve doçentlik jürilerindeki görevlerim, doktora derslerim durmaksızın devam etti. Hiçbirinde bir aksama olmadı ama ilave olarak akademik bir şey üretemedim. Bu süreçte hakkımı ailemden yana kullandım diyebilirim. (S)” paylaşımında bulunarak akademik üretkenliğinin durma nedenlerini de açıklamıştır. Akademik çalışma yapabilen akademisyen annelerden biri ise tercihlerini ifade ederken "Doçentlik hazırlığını gündemime almadım. Çok da verimsiz geçti diyemem, elimden çıkan işlerin sayısı arttı ama çok daha iyi olabilirdi.” sözleriyle performansının doçentlik için yeterli olmadığına vurgu yapmış ve bu şartlar altında doçentlik başvurusu için gerekli çalışmalarını hızlandıramadığını belirtmiştir. Söz konusu katılımcının "Çok verimsiz geçti diyemem" ifadesi diğer katılımcıların ifadesinden farklı ve istisnai olduğu için detayları görüşülmüştür. Covid-19 salgının başlamasıyla birlikte eve düzenli olarak gelen yardımcının ara vermesi, aile büyüklerinin 
şehir dışında olması ve eş desteğinin çok sınırlı kalması nedeniyle katılımcının eve yatılı bakıcı istihdam ederek desteği bu yolla sağladığı öğrenilmiştir. Çalışmada akademik anlamda kendilerini "üretken" olarak tanımlayan akademisyen anneler de dahil olmak üzere bütün anneler performanslarından memnun olmadıklarını çeşitli biçimlerde vurgulamışlardır. Bu nedenle akademik verimsizlik kodu frekansı 19 olarak iş-aile çatışması kodundan sonra en çok vurgu yapılan ikinci kod olarak tespit edilmiştir. Diğer bir deyişle Covid 19 salgını sırasında akademisyen annelerin söylemlerinde iki temel vurgu bulunmaktadır. Bunlardan ilki iş-aile çatışması iken, ikincisi akademik verimsizliktir.

\section{Kod İlişkileri Tarayıcısı}

Kod ilişkileri tarayıcısı, belirlenmiş ve atanmış kodların birbirleri ile olan ilişkilerini belgeler bazında analiz ederek görselleştirmektedir. Diğer bir deyişle, kodlar arasındaki nedensellik ilişkisini ortaya koymaktadır. Maxqda Plus 2020 programı, katılımcılardan elde edilen verilerin metin haline getirilmesinden sonra tematik kodlamaya olanak sağlamaktadır. Söz konusu kodlama sonucunda metin belgelerinde en fazla birlikte kodlananı ayırarak, söz konusu kodlar arasında ilişki olduğunu varsaymaktadır. Bu çalışmada kod ilişkileri tarayıcısı oluşturulmasındaki temel amaç; Covid-19 salgınında akademisyen annelerin edindikleri deneyimlerin hangileri arasında yoğun etkileşim olduğu konusunda okuyucuyu bilgilendirmektir. Diğer bir deyişle, iş-aile çatışması, çok yönlü sorumluluk, sınır bulanıklığı, suçluluk hissi, yorgunluk hissi, akademik verimsizlik ve akademisyen anne olma kodları arasında hangilerinin yoğun etkileşim içinde olduğunu okuyucuya görselleştirerek sunmaktır. 


\section{Şekil 7. Kod İlişkileri Tarayıcısı}

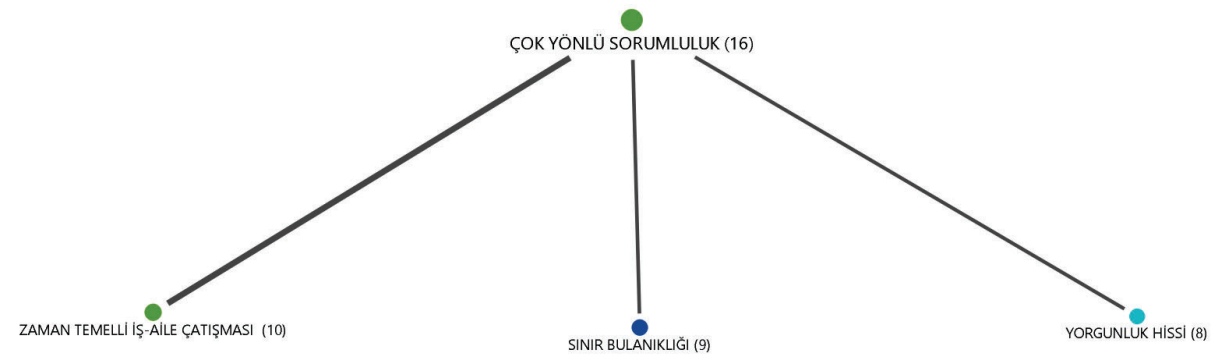

Çalışmada, çok yönlü sorumluluk deneyiminin zaman temelli çatışma, sınır bulanıklığı ve yorgunluk hissiyle ilişkili olduğu gözlemlenmektedir. Eşlerine ve diğer aile fertlerine göre sorumluluklar noktasında merkezde kabul edilen akademisyen anneler, yapmaları gereken işlere zaman bakımından yetişememekte ve bu nedenle birçok sorumluluğu eş zamanlı olarak yerine getirmek zorunda kalmaktadırlar. Çoğunlukla uykularından, kişisel zamanlarından ve alanlarından feragat eden akademisyen anneler kendilerini "yorgun" olarak tanımlamaktadırlar. Katılımcılardan biri "Kendimden çok feragat ettiğim yorgun bir süreç. (Ç)” ifadesi ile hem yorgunluğunu hem de sinırlarının ortadan kalktığını ifade ederken, bir diğer katılımc1 "Hem öğretmen hem ebeveyn hem hoca hem de akademisyen oldum ve müthiş yoruldum. (G)" ifadesi ile yaşadıkları süreci ortaya koymaya çalışmıştır.

\section{Kelime Bulutları}

Kelime bulutları, görüşmeler sırasında katılımcıların en çok kullandığı sözcüklerden oluşmaktadır. Katılımcıların konuşma sırasında en çok vurgu yaptıkları diğer bir deyişle frekansı en yüksek sözcük, kelime bulutunun ortasında yer almaktadır. Katılımcıların en çok kullandığı diğer sözcükler ise en çok kullanılan sözcüğün etrafında yer almakta ve böylece kelime bulutu oluşmaktadır. Kelime bulutları sayesinde katılımcıların en çok kullandıkları sözcükler 
tespit edilmektedir. Kelime bulutları, araştırma konusu ile katılımcının düşüncesi arasındaki ilişki hakkında ipucu barındırması nedeniyle önem taşımaktadır. Çalışmada akademisyen annelere, "size göre akademisyen anne kimdir?" sorusu yöneltilmiş, alınan cevaplar çalışmada "akademisyen anne" kodu ile yer almıştır. Bu sorudan elde edilen tanımlamalardan yola çıkılarak elde edilen kelime bulutu Şekil 8'de yer almaktadır.

\section{Şekil 8. Akademisyen Anne Kodu Kelime Bulutu}

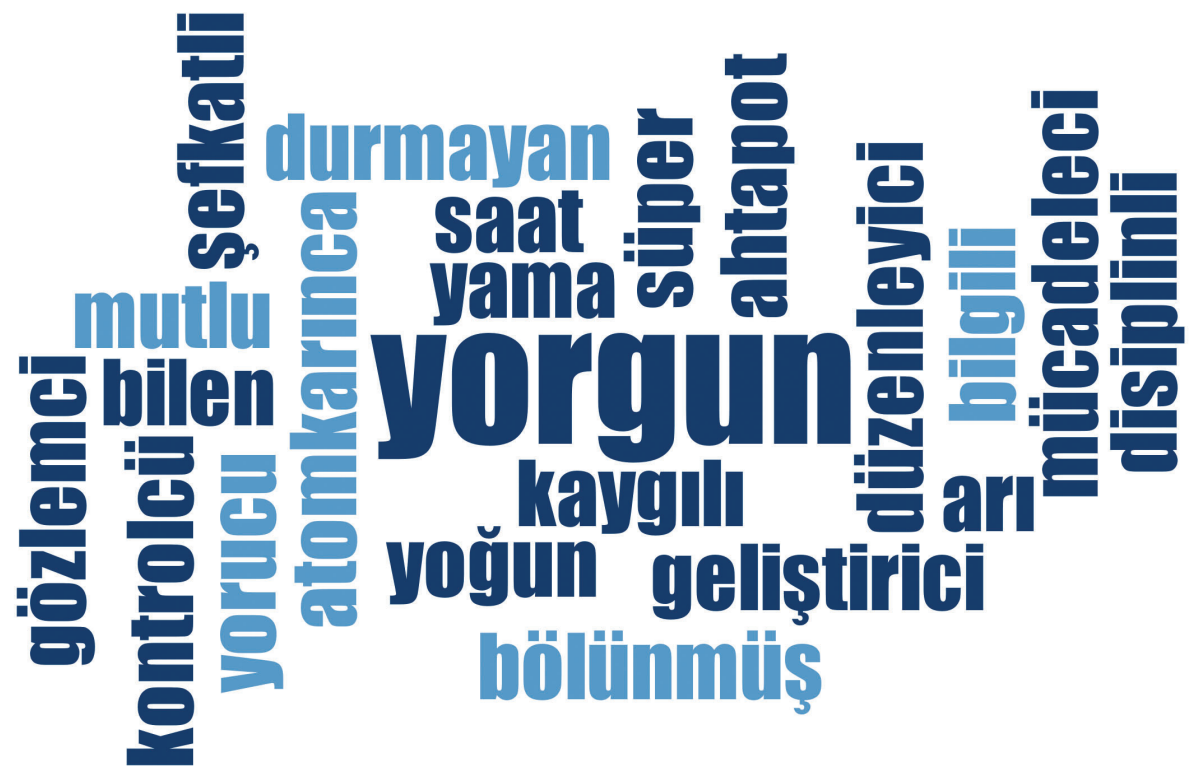

"Çalı̧̧mada akademisyen anne kimdir?" sorusuna verilen yanıtlar ışığında oluşturulan kelime bulutunda "yorgun" kelimesi bulutun ortasında konumlanmıştır. Başka bir deyişle, akademisyen anneler kendilerini tanımlarken en çok "yorgun" nitelemesini kullanmıştır. Bu nedenle söz konusu kelime frekansı en yüksek kelime olarak bulutun ortasında yer almıştır. Ayrıca akademisyen anneler, yorucu, yoğun, arı, saat, atom karınca, yama, ahtapot gibi tanımlamalar ile salgın süresince kendilerini ve yaptıkları işleri tanımlarken mücadele halinde olma ve işlere yetişme kaygısına 
vurgu yapmışlardır. Bu bağlamda akademisyen annelerin bu süreçte tüm rollerinde kendi ifadeleriyle "çok sıkı” çalıştıkları ve “yorgun” düştüklerini söylemek mümkündür. Nitekim katılımc1lardan gelen "Yarın ne yapacă̆ım, yemeğim ne olacak, çocuklarla ne yapılacak, temizlik programı ne olacak diye planlama yaptım. Çok uykusuz bir dönem başladı. Geceleri yoğun olarak çalışıyor, gündüzleri çocuklara ayırıyordum. Eşimden aldığım destek çok sınırlıydı. Ben bölünmüş, uykusuz ve yorgun bir şekilde devam etmeye çalıştım. (F)" ifadesi söz konusu tespiti destekler niteliktedir. Öte yandan, "Bu kadar stres ve endişe ile ders verip, çocuklarıma da faydalı olmaya çalışmak beni zihinsel olarak çok yordu. Kısacası bu süreçte hem fiziksel hem de zihinsel olarak yoruldum. Atom karıncayım herhalde ben dedim. (S)" ifadesinin yanı sıra "Her şeye yetişen ben, tüm açılları kapatmaya çalışıyordum, tıpkı bir yama gibi... (D)" ifadesi ve "Pandemi sürecinde tıkır tıkır işleyen bir saat gibi oldum. Her şey düzen içinde, döngüsel ve olması gerektiği gibiydi. (O)" söylemleri ile akademisyen annelerin kendileriyle ilgili metaforik tanımlamalarında "hiç durmadan çalışan, eksikleri gideren, her şeyi zamanında yapan” şeklinde açıklamaları dikkat çekmiştir.

\section{Sonuç}

Covid-19 salgını, toplumun her kesimi gibi üniversiteleri de çarpıcı bir şekilde etkilemiştir. Salgının yayılmasını önlemek amacryla üniversitelerin uzaktan eğitim-öğretim sistemine geçişiyle birlikte akademisyenler, evden çalışmak durumunda kalmışlardır. $\mathrm{Bu}$ durum, akademisyenlerin sadece eğitim-öğretim faaliyetlerini ev ortamından yürütmek durumunda kalmalarına neden olmamış, aynı zamanda akademik atama ve yükseltmelerinde kritik bir başarı göstergesi olan makale, kitap yazma gibi akademik faaliyetlerinin de eve taşınmasıyla sonuçlanmıştır. Evden çalışmanın, ideal akademisyen tanımında yer alan ve üretken, kariyer odaklı 7/24 erişilebilir ve çocuk bakım sorumluluklarından muaf olma gibi eril olmayı çağrıştıran nitelikleri daha da ön plana çıkardığı ileri sürülebilir. 
Söz konusu durumun, evden çalışmanın beraberinde getirdiği çocuk bakımı ve ev içi iş yükündeki artışla birlikte özellikle akademisyen anneleri etkileyeceği, akademideki cinsiyet eşitsizliğini pekiştireceği tahmin edilmektedir. Bu doğrultuda bu çalışmada, akademisyen annelerle görüşmeler gerçekleştirilerek iş ve özel yaşam deneyimlerinin anlaşılması amaçlanmıştır.

Çalışmadan elde edilen bulgular, araştırma yürütme ve yayın yapmanın, akademisyen anneler açısından zorlaştığını göstermektedir. Özellikle ev işleri ve çocuk bakımındaki eşitsizliklerin bir hayli artmasının akademisyen annelerin üretkenliklerine ket vurarak akademik verimsizlik yaşamalarına neden olduğu gözlemlenmektedir. Söz konusu durum, akademisyen annelerin sosyo-kültürel olarak inşa edilen cinsiyet eşitsizliği ile mücadele ettiklerini göstermektedir. Bu mücadele, akademisyen annelerin yayın yapma performanslarından taviz verip aile hayatlarına odaklanmalarıyla sonuçlanmaktadır. Diğer bir ifadeyle süreklilik gösteren tüm sorumlulukları nedeniyle, akademisyen annelerin araştırma yapmak için vakit bulamadıkları ve yayın yapma performanslarından taviz verip aile hayatlarına odaklandıkları belirtilebilir. Salgın döneminde akademisyen anneler, araştırmalarına odaklanmaya çalıştıklarında çocuklarıyla ilgilenemedikleri için kendilerini suçlu hissettiklerini de ifade etmişlerdir.

Akademisyenler akademik atama ve yükseltmelerde cinsiyet farkı gözetmeksizin değerlendirildikleri için yayın üretkenliklerindeki bu kısa vadeli değişikliklerin uzun vadede kariyerlerini etkileyeceğinden endişe etmektedirler (Minello, 2020: 2). Nitekim, araştırmaya katılan altı doktor öğretim üyesi anneden sadece biri doçentlik dosyasını tamamlayabildiğini ve sürecin kendisi için çok sancılı geçtiğini ifade etmiştir. Söz konusu katılımcının da yine aile büyüğü desteği alarak, çocuk bakımı ve ev işleri konusunda göreli olarak daha az zaman harcadığı belirtilmiştir. Nitekim söz konusu katılımcının "bekar akademisyen anne" olduğu ev içi baba desteğinin hiç olmadığı, sadece aile büyüğü (anneanne) desteği aldığını ifade etmekte fayda vardır. 
$\mathrm{Bu}$ çalışmanın; Covid-19 salgınının beraberinde getirdiği artan ev içi iş yükünün akademisyen anneler aleyhine yarattı̆̆ cinsiyet eşitsizliğini göstermesi nedeniyle önemli olduğu düşünülmektedir. Görüşmelerden elde edilen bulgular, salgının etkilerinin uzun süre devam etmesi halinde akademisyen anneler için kariyer eşitsizliklerinin giderek büyüyebileceğine işaret etmektedir. Nitekim çalışmada ortaya çıkan bir diğer konu, söz konusu eşitsizliğin akademisyen anne üzerinde "gerilim"e neden olduğudur. Kuşkusuz çalışmaya katılan akademisyen annelerin bulunduğu unvan (Prof. Dr., Doç.Dr., Dr. Öğrt. Üyesi), sahip olduğu çocuk sayısı ve annenin medeni durumu; edindiği deneyimi farklılaştırmaktadır. Bununla birlikte katılımcıların neredeyse tamamı Covid-19 döneminde işyaşam dengelerinde olumsuz deneyimler edindiklerini ifade etmektedirler.

Çalışmaya katılan akademisyen anneler, eş desteğinin çok sınırlı kaldığına özellikle vurgu yapmaktadırlar. Söz konusu sınırlı desteğin; market alışverişi yapmak, çay-kahve hazırlamak, çocuklarla etkinlik yapmak şeklinde belirli ve nispeten daha kolay alanlarda kendini gösterdiği ifade edilmektedir. Öte yandan günün tamamı için öğün hazırlamak, çocukların ders ve ödevlerine yardımcı olmak, evin hijyenini sağlamak ve hatta alışveriş sonrası market ürünlerinin hijyenini sağlamak da akademisyen annelerin mevcutta devam eden sorumluluklarına eklenmiştir. Bu nedenle söz konusu dönemde akademisyen annelerin; güne erken başlama, özel alanlarını iptal etme, hobi vb. etkinliklerini ertelemesiyle sonuçlanan; iç-çatışmalarını, suçluluk hislerini ve kaygılarını arttıran ve dolayısıyla verimliliklerini azaltan iş-yaşam deneyimi gözlemlenmektedir.

Bilim ve yenilik, çeşitlilikten yararlanarak ilerlemektedir. Ancak Covid-19 salgını esnasında akademisyen annelerin üretkenliklerinin ve akademik yayınlarının orantısız bir şekilde olumsuz etkilenmesi, kadınların bilimsel uzmanlı̆̆ının kamusal alandan kaybolması tehlikesini ortaya çıkarmaktadır (Burzynska \& Contreras, 2020, s.1968). Bu doğrultuda elde edilen bulgular ışı̆̆ında, 
salgının beraberinde getirdiği cinsiyet eşitsizliklerinden akademisyen annelerin mağdur olmamaları için birtakım öneriler getirilmesi uygun görülmüsşür. Buna göre bazı üniversitelerde, uzaktan eğitimin daha verimli geçmesi için eğitimlerin düzenlenmeye başladığ görülmektedir. Söz konusu eğitimlerin, uzaktan eğitimin yüz yüze eğitimden farklı dinamiklerinin olması nedeniyle eğitimde kaliteyi arttırmak amacıyla yararlı olacağı düşünülmektedir. Üniversitelerin uzaktan eğitimde kaliteyi arttırmanın yanı sıra iş-yaşam dengesi eğitimleri vermesi de önerilebilir. Ayrıca üniversiteler, yeni dönemlerini planlarken ve kararlar alırken yeni normalleri gözeterek akademideki cinsiyet uçurumunu ve cinsiyete dayalı verimlilik düşüşlerini azaltıcı politikalara yönelebilirler.

Covid-19 gibi dünya genelini etkileyen bir salginda öngörülenden çok daha fazla sayıda kadının olumsuz yönde etkilendiği düşünülmektedir. $\mathrm{Bu}$ araştırma, çalışan annelerin özel bir grubunu oluşturan akademisyen annelerin derinlemesine görüşmelerle salgin döneminde iş-yaşam dengeleri ve kariyerlerinde yaşadıkları sorunları ortaya çıkarmayı amaçlamaktadır. Salgının akademisyenler üzerindeki etkilerini inceleyen çalışmaların daha çok cinsiyete göre yayın sayısı üzerinden gittiği ve kadın akademisyenler arasında anne olanlarla olmayanlar arasında ayrım yapılmadığ gözlemlenmektedir. Bu durum, salgının beraberinde getirdiği cinsiyet eşitsizliğinden önemli ölçüde etkilendikleri tahmin edilen akademisyen annelerin durumuna ilişkin tartışmaların eksik kalmasına neden olmaktadır. Bu anlamda çalışmanın salgın döneminde akademisyen annelerin iş-yaşam deneyimlerine ışık tutması açısından literatüre katkı sağladığı düşünülmektedir. 


\section{Kaynakça}

Acker, J. (1992). Gendering organizational theory. Editörler: Jay M. Shafritz, Ott \& Jang, Classics of organizational theory, 450-459.

Andersen, J P., Nielsen, M. W., Simone, N. L., Lewiss, R. E. ve Jagsi, R. (2020). Meta-Research: COVID-19 medical papers have fewer women first authors than expected. Elife, 1-7.

Baltacı, A. (2019). Nitel Araştırma Süreci: Nitel Bir Araştırma Nasıl Yapılır? Ahi Evran Üniversitesi Sosyal Bilimler Enstitüsü Dergisi (AEÜSBED) 2019, Cilt 5, Say 2, 368-388.

Barnes, C. M., Wagner, D. T. ve Ghumman, S. (2012). Borrowing from sleep to pay work and family: Expanding time-based conflict to the broader nonwork domain. Personnel Psychology, 65(4), 789-819.

Başarır, F. ve Sarı, M. (2015). Kadın Akademisyenlerin” Kadın Akademisyen Olma” ya İlişkin Algılarının Metaforlar Yoluyla İncelenmesi. Journal of Higher Education \& Science/Yüksekögretim ve Bilim Dergisi, 5(1), 41-51.

Burzynska, K. ve Contreras, G. (2020). Gendered effects of school closures during the COVID-19 pandemic. The Lancet, 395(10242), 1968.

Buzzanell, P. M., Meisenbach, R., Remke, R., Liu, M., Bowers, V. ve Conn, C. (2005). The good working mother: Managerial women's sensemaking and feelings about work-family issues. Communication Studies, 56(3), 261-285.

Coltrane, S. (2004). Elite careers and family commitment: It's (still) about gender. The Annals of the American Academy of Political and Social Science, 596(1), 214-220.

Creswell, J. W. (2018). Nitel Araştırma Yöntemleri, Beş Yaklaşıma Göre Nitel Araştırma ve Araştırma Deseni, Ankara: Siyasal Kitabevi.

Cui, R., Ding, H. ve Zhu, F. (2020). Gender Inequality in Research Productivity During the COVID-19 Pandemic. SSRN 3623492, 1-20.

Cummins, H. A. (2005). Mommy tracking single women in academia when they are not mommies, Women's Studies International Forum, 28(2/3), 222-31.

Currie, J., Harris, P. ve Thiele, B. (2000). Sacrifices in greedy institutions: are they gendered? Gender and Education, 12(3), 269-91.

Edwards, J. R. ve Rothbard, N. P. (2000). Mechanisms linking work and family: Clarifying the relationship between work and family constructs. Academy of management review, 25(1), 178-199. 
Forster, N. (2000). A case study of women academics' views on equal opportunities, career prospects and work-family conflicts in a British university. Career Development International, 6(1), 28-38.

Greenhaus, J. H. ve Beutell, N. J. (1985). Sources of conflict between work and family roles. Academy of management review, 10(1), 76-88.

Hauser, O. (2012). Pushing daddy away? A qualitative study of maternal gatekeeping. Qualitative Sociology Review, 8(1), 34-59.

Herschberg, C., Benschop, Y. ve van den Brink, M. (2018). Precarious postdocs: A comparative study on recruitment and selection of early-career researchers. Scandinavian Journal of Management, 34(4), 303-310.

Hoskins, K. (2010). The price of success? The experiences of three senior working class female academics in the UK. In Women's Studies International Forum, 33(2), 134-140.

ILO (2021). Working from home: From invisibility to decent work, Geneva: ILO.

Ivancheva, M., Lynch, K. ve Keating, K. (2019). Precarity, gender and care in the neoliberal academy. Gender, Work \& Organization, 26(4), 448462 .

Kahn, R. L., Wolfe, D. M., Quinn, R. P., Snoek, J. D. ve Rosenthal, R. A. (1964). Organizational stress: Studies in role conflict and ambiguity. John Wiley.

Lewis, H. (2020). The coronavirus is a disaster for feminism: Pandemics affect men and women differently, The Atlantic (https://www.theatlantic.com/international/archive/2020/03/feminism-womensrights-coronavirus-covid19/608302/)

Lundberg, S. ve Rose, E. (2002). The effects of sons and daughters on men's labor supply and wages. Review of Economics and Statistics, 84(2), 251-268.

Magadley, W. (2019). Moonlighting in academia: a study of gender differences in work-family conflict among academics. Community, Work \& Family, 1-20.

Manzo, L. K. C. ve Minello, A. (2020). Mothers, childcare duties, and remote working under COVID-19 lockdown in Italy: Cultivating communities of care. Dialogues in Human Geography,10(2), 120-123.

Minello, A. (2020). The pandemic and the female academic. Nature 10, 1-3.

Nash, M. ve Churchill, B. (2020). Caring during COVID-19: A gendered analysis of Australian university responses to managing remote working and caring responsibilities. Gender, Work \& Organization, 1-24. 
Nikunen, M. (2012). Changing university work, freedom, flexibility and family. Studies in Higher Education, 37(6), 713-29.

O'Reilly, A. (2020). "Trying to Function in the Unfunctionable": Mothers and COVID-19. Journal of the Motherhood Initiative for Research and Community Involvement, 11(1), 7-18.

Oleschuk, M. (2020). Gender equity considerations for tenure and promotion during COVID-19. Canadian Review of Sociology, 1-14.

Patton, W. ve McMahon, M. (2006). The systems theory framework of career development and counseling: Connecting theory and practice. International Journal for the Advancement of Counselling, 28(2), 153-166.

Pinho-Gomes, A. C., Peters, S., Thompson, K., Hockham, C., Ripullone, K., Woodward, M. ve Carcel, C. (2020). Where are the women? Gender inequalities in COVID-19 research authorship. BMJ Global Health, $5(7), 1-4$.

Raburu, P. A. (2015). Motivation of women academics and balancing family \& career, Journal of Educational and Social Research, 5(1), 359-370.

Sandelowski, M. (1986). The problem of rigor in qualitative research. Advances in Nursing Science, 8(3), 27-37.

Santos, G. G. ve Cabral-Cardoso, C. (2008). Work-family culture in academia: a gendered view of work-family conflict and coping strategies. Gender in Management: An International Journal, 23(6), 442-57.

Shin, M. D., Shukla, S., Chung, Y. H., Beiss, V., Chan, S. K., Ortega-Rivera, O. A., Wirth, D. M., Chen, A., Sack, M., Pokorski, J. K. ve Steinmetz, N. F. (2020). COVID-19 vaccine development and a potential nanomaterial path forward. Nature nanotechnology, 15(8), 646-655.

Sommerkorn, I. (1996). On the position of women in the university teaching profession in England, PhD thesis, University of London.

Sutherland, M. (1985). Women Who Teach in Universities, Trentham, London.

Spalter-Roth, R. and Erskine, W. (2005). Beyond the fear factor: work/family policies in academia - resources or rewards? Change: The Magazine of Higher Learning, 37(6), 19-25.

Steiber, N. (2009). Reported levels of time-based and strain-based conflict between work and family roles in Europe: A multilevel approach. Social Indicators Research, 93(3), 469-488.

Strauss, A. ve Corbin, J. M. (1990). Basics of qualitative research: Grounded theory procedures and techniques. Sage Publications, Inc.

Sullivan, S. E. (1999). The changing nature of careers: A review and research agenda. Journal of Management, 25(3), 457-484. 
Şentürk, İ. (2000). Üniversitede Kadın Olmak: Akademik Örgütte Toplumsal Cinsiyet Sorunu: Nitel Bir Çalışma. Kadin/Woman 2000, 13(2).

Toffoletti, K. ve Starr, K. (2016). Women academics and work-life balance: Gendered discourses of work and care. Gender, Work \& Organization, 23(5), 489-504.

Waters, M. and Bardoel, E.A. (2006). Work-family policies in the context of higher education: useful or symbolic? Asia-Pacific Journal of Human Resources, 44(1), 67-82.

Woodward, D. (2007). Work-life balance strategies used by women managers in British 'modern' universities. Equal Opportunities International: Equality, Diversity and Inclusion, 26(1), 6-17.

Yağar, F. ve Dökme S. (2018). Niteliksel Araştırmaların Planlanması: Araştırma Soruları, Örneklem Seçimi, Geçerlik ve Güvenirlik. Gazi Bilimleri Dergisi, 2018: 3(3) :1-9.

Yıldırım A., Şimşek H. (2016). Sosyal Bilimlerde Nitel Araştırma Yöntemleri, Ankara: Seçkin Yayıncılık.

https://www.icisleri.gov.tr/81-il-valiligine-tam-kapanma-tedbirlerigenelgesi-gonderildi=30 Nisan 2021 


\section{Ek 1: Görüşme Soruları}

1. Akademik unvanınız nedir?

2. Kaç yaşındasınız?

3. Eşiniz ne iş yapıyor?

4. İdari göreviniz var mı?

5. Salgın dönemindeki haftalık ders yükünüz nedir?

6. Kaç çocuğunuz var?

7. Çocuk/çocuklarınızın yaşını belirtir misiniz?

8. Salgının beraberinde getirdiği uzaktan eğitim öncesinde bir gününüzü nasıl planlar ve geçirirdiniz?

9. Salgının beraberinde getirdiği uzaktan eğitim süresince bir gününüzü nasıl planlıyor ve geçiriyorsunuz?

10. Salgının beraberinde getirdiği uzaktan eğitim sürecinde öncelikleriniz değişti mi? Nasıl?

11. Salgının beraberinde getirdiği uzaktan eğitim sürecince iş-yaşam dengesini kurmakta zorlandığınız oldu mu? Zorlandığınız konular neler?

12. Salgının beraberinde getirdiği uzaktan eğitim süresince işyaşam dengesini kurmakta zorlandığınız konulara nasıl çözümler buldunuz?

13. Uzaktan eğitime geçilmesi, akademik faaliyetlerinizdeki (örneğin: kitap, kitap bölümü, makale, bildiri, araştırma projesi yazımı vb.) üretkenliğinizi nasıl etkiledi?

14. Salgınla birlikte geçilen uzaktan eğitim öncesi ve sonrası dönemleri karşılaştırdığınızda akademik çıktılarınızın (örneğin: kitap, kitap bölümü, makale, bildiri, araştırma projesi vb.) bir karşılaştırmasını yapar mısınız?

15. Akademisyen bir anne olarak kendinizi nasıl tanımlarsınız? 